\title{
Sosialisasi Olahraga Petanque Pada Siswa Smp Negeri 2 Tambang Kecamatan Tambang Kabupaten Kampar
}

\author{
Mimi Yulianti ${ }^{1}$, Leni Apriani ${ }^{1}$, Sri Rezeki Amelia ${ }^{1}$, Saifullah ${ }^{1}$ \\ ${ }^{1}$ Program Studi Penjaskesrek, Fakultas IlmuPendidikan Dan Keguruan, Universitas Islam Riau, JL. \\ Kaharuddin Nasution No 113 Marpoyan, Pekanbaru, Riau, Indonesia - 28284 \\ *Penulis koresponden: mimipenjas@edu.uir.ac.id
}

\begin{tabular}{l}
\hline \hline Info Artikel \\
\hline Riwayat: \\
Dikirim 11 Desember 2021 \\
Direvisi 31 Desember 2021 \\
Diterima 11 Januari 2022 \\
\hline
\end{tabular}

\section{Kata Kunci :}

Sosialisasi

Olahraga

Petanque

Siswa

\begin{abstract}
Abstrak
Tujuan dari kegiatan ini adalah untuk memeperkenalkan olahraga Petanque kepada siswa yang ada di SMP Negeri 2 tambang. Pengabdian ini dilakukan di Lapangan SMP Negeri 2 Tambang. Materi yang diberikan dalam pengabdian ini tentang teknik dan peraturan yang digunakan dalam permainan olahraga petanque. Kegiatan sosialisai ini dilaksanakan dengan metode demonstrasi tentang pelaksanaan permaina petanque Dari kegiatan yang dilakukan diharapkan lahirnya atlit-atlit petanque yang profesional yang bisa mengikuti even-even kejuaraan baik itu yang di tingkat daerash maupun di tingkat nasional dan internasional
\end{abstract}

\section{PENDAHULUAN}

Petanque [dibaca Pe tak] adalah olahraga yang berasal dari Perancis permainan ketangkasan melempar bola yang terbuat dari besi metal [boules] mendekati bola target yang terbuat dari kayu [Jack]. Petanque dimainkan di lapangan berukuran $4 \mathrm{~m}$ x $15 \mathrm{~m}$ di atas permukaan tanah keras atau rumput.

Bentuk asli permainan ini muncul tahun 1907 di La Ciotat, di Provence, di selatan Perancis. Namanya berasal dari Les Ped Tanco dalam dialek Provençal di bahasa Occitan, yang berarti "kaki rapat." Permainan Pétanque dimainkan oleh sekitar 17 juta orang di Perancis, kebanyakan selama liburan musim panas. Terdapat 375.000 pemain dengan lisensi dari Fédération Française de Pétanque et Jeu Provençal (FFPJP) dan 3000 di Inggris.

Petanque termasuk olah raga baru di Indonesia, namun petanque sebenarnya termasuk olah raga yang sudah punya nama. Di dunia, negara-negara yang kuat dan konsisten mengembangkan petanque adalah negara-negara yang pernah dijajah oleh Prancis, negara yang memang melahirkan cabang olah raga tersebut. Pada pesta olahraga SEA Games Tahun 2011 di Indonesia, Pétanque sudah menjadi salah satu cabang olahraga yang dipertandingkan. Lazimnya cabang olahraga lainnya, petanque di SEA Games dimasukkan dalam kategori olahraga konsentrasi, mempunyai prasyarat tertentu. Permainan ini biasa dimainkan di tanah keras atau minyak, tapi juga dapat dimainkan di rerumputan, pasir atau permukaan tanah lain.

Olahraga petanque ini sebenarnya sudah mulai berkembang di kabupaten kampar, buktinya sudah ada beberapa orang pelatih yang memiliki lisensi pe;latih tingkat provinsi, namun perkembvangan petanque itu sendiri masih belum merata penyebarannya ke daerah-daerah yang ada di kabupaten kampar. Masih banyak sekolah-sekolah yang ada dikabupaten kamapr yang belum mengembangkan olahraga petanque di sekolah mereka.

Tiga Pilar pengembangan keolahragaan mliputi olahraga pendidikan, olahraga prestasi dan olahraga rekreasi merupakan wadah yang sangat ideal untuk pengembangan sebuah cabang olahraga (Nala dalam Kholik \& Zulham, 2020). Pilar olahraga pendidikan, memberikian peluang pada olahraga ini akan masuk kedalam kurikulum PJOK. Sosialisasi yang baik dan dilakukan secara berkelanjutan akan mengenalkan olahraga petanque ini kepada masyarakat pendidikan. 
Perkembangan olahraga ini tentunya bisa digunakan sebagai salah satu alat dalam pembelajaran PJOK yang diselaenggarakan di SD dan SMP di kabupaten Kampar.

Berdasarkan uraian di atas, dimana olahraga petanque sudah masuk dalam pesta SEA Games, maka diperlukan suatu usaha untuk mensosialisasikan ke daerah-daerah sehingga diharapkan akan memperoleh atlet petanque yang nantinya mempunyai kemampuan yang matang untuk mencapai prestasi baik di tingkat nasional maupun internasional.

\section{METODE PELAKSANAAN}

Kegiatan Pengabdian Kepada Masayarakat ini dilaksanakan di SMP Negeri 2 Tambang yang beralamatkan di Jl Raya Pekanbaru Bangkinang KM. 24, Rimbo Panjang, Kecamatan Tambang, Kabupaten Kampar. Waktu pelaksanaan kegiatan yaitu di bulan November 2021.

Metode yang digunakan dalam kegiatan pengabdian masyarakat ini adalah 1) Metode ceramah yaitu menyampaikan meteri olahraga petanque yang mencangkup hakekat olahraga petanque, fasilitas dan alat-alat, serta peraturan permainan petanque dengan menggunakan media proyektor. 2) Metode demontrasi yaitu diberikan pelatihan teknik dasar bermain petanque. 3) Metode diskusi yaitu melaksanakan diskusi pada penyampaian materi maupun praktik lapangan mengenai olahraga petanque. 4) Koordinasi Olahraga dalam kegiatan ini berpartisipasi dalam menyediakan tempat dan waktu untuk melakukan pengabdian kepada masyarakat. 5) Tindak lanjut dari kegiatan ini akan dilaksanakan sosialisasi olahraga petanque untuk tingkat Kecamatan.

\section{HASIL DAN PEMBAHASAN}

Kegiatan sosialisasi ini memberikan kesan yang sangat baik dalam mengenalkan olahraga petanque kepada siswa/siswi SMPN 2 Tambang. Langkah pertama yang dilakukan dalam memberikan pengetahuan secara teori kepada peserta tentang asal usul olahraga petanque selanjutnya menjelaskan sarana dan prasarana yang digunakan dalam olahraga petanque, serta menjelaskan aturan dan cara bermain dalam olahraga petanque.

\section{KESIMPULAN}

Kesimpulan yang bisa diambil dari pelaksanan sosialisasi olahraga Petanqque pada siswa SMPN 2 Tambang Antara lain

1. Dengan pelaksanaan Sosialisasi ini dapat memperkenalkan kepada siswa SMPN 2 Tambang tentang olahraga petanque

2. Dapat memperkenalkan kepada siswa teknik bermain olahragta petanque

3. Menumbuhkan semangat berlatih siswa

\section{UCAPAN TERIMA KASIH}

Ucapan terimakasih penulis ucapkan kepada pihak sekolah SMPN 2 Tambang atas kesedian mnyediakan tempat untuk pelaksanaan kegiatan pengabdian kepada masyarakat ini. Dan juga ucapan terimakasih penulis ucapkan kepada pihak DPPM Universitas Islam Riau yang telah memfasilitasi penulis untuk melaksanakan kegiatan pengabdian kepada masyarakat.

\section{DAFTAR PUSTAKA}

Balfasa, S. A., Putra, A. M., \& Putri, M. W. (2021). Jurnal MUI: Muhammadiyah Untuk Indonesia. Juhanis, B, B., \& Nur, M. (2017). Pelatihan Teknik Dasar dan Sosialisasi Peraturan Permaian Olahraga Petanque pada Mahasiswa FIK UNM Makassar. Pengabdian Kepada Masyarakat $\begin{array}{llll}\text { Universitas Negeri } & \text { Makassar, } & \text { 137- }\end{array}$ 141.http://ojs.unm.ac.id/semnaslpm/article/view/7816

Okilanda, A. (2018). Revitalisasi Masyarakat Urban/Perkotaan Melalui Olahraga Petanque. Halaman Olahraga Nusantara, 1(1), 86-98.

Sari, Y., Kepelatihan olahraga, P., \& P e m banguna n, U. T. (2021). Sosialisasi Cabang Olahraga Petanque Pada Guru Smp. 2(3), 14-22. 
Buletin Pembangunan Berkelanjutan

Vol. 5 No. 3, Desember 2021 hal. 69-71

UU No 3 Tahun 2005. (2005). Undang-Undang Republik Indonesia Nomor 3 Tahun 2005 Tentang Sistem Keolahragaan Nasional Dengan. Presiden RI, 1, 1-53. 